IRSTI 06.52.41.

\author{
L. Statsenko \\ University of South Australia, Australia, Adelaide, \\ e-mail: larissa.stasenko@unisa.edu.au
}

\title{
CHANGE OF FACTORS OF POPULATION LIVING IN THE CONDITIONS OF USING DIGITAL TECHNOLOGIES
}

The transition to digitalization and the implementation by digital technologies in all aspects of the economic and social life of society as a whole and of a person separately is turning into a driving force that ensures efficiency in such areas as the economy, society and improving life standards. In a broad sense, digitalization is seen as a key trend effective global development. At the same time, digital communication technologies (ICT) and their transformation must meet such requirements as widespread introduction into business production, science, the social sphere and the daily life of citizens. The ubiquitous coverage of digital technologies must also be accompanied by their accessibility for both professionals and ordinary citizens, that is, we are talking about the need for the availability and development of skills in working with information and communication technologies. The great possibilities of presenting digital information lead to the fact that digitalization is associated with the formation of a huge layer of platforms, among which ecosystems are innovative and highly relevant, which provides the user with the creation of a favorable environment and thus solve whole groups of problems. Ensuring digital literacy of the population of any society is the key to its successful development, a priority task of the state. The implementation of a program for widespread development and provision of digital technologies in society is a guarantor and incentive to develop and increase the level and quality of life of citizens.

Key words: digital economy, transformation, efficiency, information and communication (ICT) technologies, quality of life of the population, informatization of society, employment.

\section{Л.Г. Стаценко}

Оңтүстік Автралия Университеті, Аустралия Университеті, Аустралия қ. e-mail: larissa.stasenko@unisa.edu.au

\section{Сандық технологияларды пайдалану шарттарында халықтың өмір сүру факторларының өзгеруі}

\footnotetext{
Цифрландыруға көшу және цифрлық технологияларды тұтастай алғанда қоғамның және жеке тұлғаның экономикалық және әлеуметтік өмірінің барлық аспектілеріне енгізу экономиканың, қоғамның тиімділігін және халықтың өмір сүру сапасының жақсаруын қамтамасыз ететін қозғаушы күшке айналуда. Цифрландыру сөздің кең мағынасында, егер цифрлық түрдегі трансформация өндіріс, бизнес, ғылым, әлеуметтік сала және азаматтардың күнделікті өмірін қамту сияқты талаптарға жауап берген жағдайда ғана тиімді жаһандық дамудың тенденциясы ретінде қарастырылуы мүмкін; қолданушыларға түрлендірілген ақпараттың қол жетімділігімен және цифрландыру нәтижелерін мамандар ғана емес, қарапайым азаматтар да пайдаланған кезде; және цифрлық ақпаратты пайдаланушылар тиісті ақпараттық-коммуникациялық технологиялар (АКТ) дағдыларына ие болған жағдайда қарастыруға болады. Цифрлық ақпаратты ұсынудың үлкен мүмкіндіктері оның (цифрландыру) онсыз да интегралды технологиялық «тіршілік ету ортасын» (экожүйелер, платформалар) құрайтындығына әкеледі, оның шеңберінде пайдаланушы - технологиялық, аспаптық, әдістемелік, серіктестік және т.б. проблемалардың барлық топтарын шеше алу үшін өзіне қолайлы жағдай жасай алады. Әрбір қоғамның тұрғындарының цифрлық сауаттылығын қамтамасыз ету - оның табысты дамуының кепілі, мемлекеттің басым міндетінің бірі. Қоғамда цифрлық технологияларды кеңінен дамыту мен қамтамасыз ету бағдарламасын іске асыру азаматтардың өмір сүру деңгейі мен сапасын дамыту мен жақсартудың кепілі және ынталандырушысы болып табылады.

Түйін сөздер: цифрлық экономика, трансформация, тиімділік, ақпараттық-коммуникациялық технологиялар, халықтың өмір сүру сапасы, қоғамды ақпараттандыру, жұмыспен қамту.
} 


\title{
Л.Г. Стаценко \\ Университет Южная Австралия, Австралия, г. Аделаида, e-mail: larissa.stasenko@unisa.edu.au \\ Изменение факторов жизнедеятельности населения в условиях использования цифровых технологий
}

\begin{abstract}
Переход на цифровизацию и внедрение цифровых технологий по всем аспектам экономической и социальной жизнедеятельности общества в целом и человека в отдельности превращается в движущую силу, обеспечивающую эффективность развития экономики, общества и повышения уровня и качества жизни населения. В широком смысле слова цифровизация рассматривается как ключевая тенденция эффективного глобального развития. При этом цифровые коммуникационные технологии (ИКТ) и их трансформация должны отвечать таким требованиям, как широкое внедрение в бизнес-производство, науку, социальную сферу и повседневную жизнь граждан. Повсеместный охват цифровыми технологиями также должен сопровождаться их доступностью как для специалистов, так и обычных граждан, то есть речь идет о необходимости наличия и развития навыков работы с информационно-коммуникационными технологиями. Большие возможности представления цифровой информации приводят к тому, что цифровизация сопряжена с формированием огромного пласта платформ, среди которых инновационными и высокоактуальными являются экосистемы, что обеспечивает пользователю создание благоприятной среды и, таким образом, решение целых групп задач. Обеспечение цифровой грамотности населения любого общества - залог его успешного развития, приоритетная задача государства. Реализация программы повсеместного развития и обеспечения цифровых технологий в обществе является гарантом и стимулом для развития и повышения уровня и качества жизни граждан.

Ключевые слова: цифровая экономика, трансформация, эффективность, информационно-коммуникационные технологии (ИКТ), качество жизни населения, информатизация общества, занятость.
\end{abstract}

Introduction. The adopted government program «Digital Kazakhstan» is aimed at digitalizing economic sectors, creating an innovation system and increasing and life standards. The modern economy is characterized by rapidly developing technological changes, the signs of which are determined by such concepts and terms as technology of virtual communication and communications, blockchain, artificial intelligence and other content and characteristics that penetrate into human everyday life.

Thus, in globalization era, digitalization is key factor of nation's global competitiveness. Based on the fact that strategically significant documents in most countries of the world remain documents on digitalization, which contain key development areas: for example, the digital transformation of the economy is proclaimed in such an innovatively developed country as Singapore, in which by 2050 $50 \%$ of transport will be only electric.

In addition to the above unmanned taxis are already used in Singapore. In a European country like Germany, digitalization covers almost all sectors of the economy and spheres of human life - the broad scope consists from public administration, business, to areas such as education and science.

The peculiarity of Kazakhstan is that it is able to respond to global challenges both within international organizations and within the state, and the country is currently taking part in the process of digital transformation. (Website Global Center for Digital Business Transformation, 2018).
Kazakhstan is part of EUAU digitalization plan 2025. In wich the main directions for improvement of digital agenda of the EAEU were adopted; where «the government-for-citizens» state corporation was established nationwide, with 340 front offices providing over 38 million. services annually. There are 70 mobile Public Service Centers (PSC) in the republic to improve the availability of services to the population, including residents of remote settlements. The number of such services is about 500 thousand annually, with more than 12 thousand trips performed (Industry 4.0, 2016).

As of this year, public services registry can provide 746 public services. Implemantation of ICT in public services registy in the strategic plan will become Big Data, as a full-fledged base of new innovative technologies that fit into the concept of the digital economy and is characterized as a system for analyzing big data. In this regard, it is in modern social development that the following trend is observed as an increase in the volume of modern data, Big Data is universal and effective in concentrating a huge amount of services in a structured format in the public administration system. With the help of them, can study the tendencies of political views depending on the gender, age or profession of a person. (Gribanov Yu.I., Repin N.V., 2017: 33). In addition, big data systems can be used in trade, finance, real estate rental, and national security.

Literature review. There are numerous studies of problematic issues of digitalization and its impact 
on science as a branch of knowledge of the laws of human development. Most foreign sources, when describing the digital economy, focus on digitalization technologies.

Special state programs the digitalization process is aimed at covering all sectors of the economy and social sphere, reflecting the policy of introducing digitalization into society as a guarantee of its innovative development (State Program, 2020; About the State Program "Information Kazakhstan - 2020", 2018).

Numerous works of foreign and Kazakhstan authors should be noted, including Varavin E.V., Ziyadin S.T., Kozhakhmetova S.G., Madiyarova A., Mukhtarova K.S., Potluri Rajasekhara Mouly, Sempl M., Tarasov V. V.V., Flanders J.I., Chebotareva E.E., Chernykh S.I. and others (Varavin EV, 2017; Ziyadin, S., 2019; Mukhtarova K.S. et al., 2020; Mukhtarova K.S. et al., 2017; Potluri Rajasekhara Mouly, 2020; Semple M., 2017; V.V. Tarasov, 2018; Flanders J., 2017; Chebotareva E.E., 2017; Chernykh S.I., 2018 and others).

The digitalization development processes are successfully reflected in the activities of various international organizations - the World Bank, European Commission, NRU HSE, The Economist, etc. (World Bank, 2016; European Commission, 2018; ISSEK NRU HSE, 2019; The Economist, 2014).

Materials and methods. The scientific article used the methods of marketing, economic and logical analysis, forecast estimates, statistical data processing and other general scientific and special scientific research methods.

This article uses legislation and special national programs of the Republic of Kazakhstan, data from government statistical agencies, as well as documents of state bodies, scientific and methodological and monographic works, author's publications of foreign and domestic scientists on the problems of digitalization and determining the quality of life of citizens, information and analytical materials, periodicals on the Internet, etc.

Results and discussion. Goals to be achieved in result of "Digital economy" program realization: improving the standard of living and improving the quality of life. These goals can only be achieved by digital technologies use, both now and in the future.

The state program "Digital Kazakhstan" has set five key areas, including the following:

According to the first direction, accordingly, through the use of breakthrough innovative technologies, the main feature of state programs is the digitalization of traditional sectors of the state economy.
Result of national program implementation should be an increase in capitalization and labor productivity. Under this program, the key sectors of economy for implementing the digitalization process are considered to be: industry, logistics, transport, electricity, agro-based industries. Evaluation of the implementation of the Industry 4.0 program in these sectors was carried out with the help of foreign experts. The greatest attention was also paid to the modernization of processing and mining industries.

According to the next second section of the state program, "Transition to a digital state" for the population and business provides for the provision of opportunities for using online in a transparent and comfortable access. The implementation of the program provides for the launch of an electronic health passport.

Innovative transformations such as electronic journals and diaries have been introduced in the field of education. The system of automatic electronic distribution of children to preschool organizations in 11 cities began earlier this year. The transfer of citizens to register in electronic form will eliminate the issuance of more than 2 million certificates.

According to the third direction, the section "Implementation of the Digital Silk Road" provides for high-quality mobile coverage of the entire territory of Kazakhstan, as well as ensuring fast and safe access to Internet resources. Thus, in 1249 rural settlements, the implementation of a national public-private partnership (PPP) project to provide broadband Internet access has begun. As part of the use of Big Data, work on cybersecurity has been strengthened, for this innovative analytical laboratories are being created.

According to the fourth direction, the section "Development of human capital" of the national program provides for the development of a program for increasing digital literacy of the population in the direction of providing new competencies, which is possible due to innovative transformations in education.

Thus, great attention is paid to the improvement of the new creative and critical thinking. We would like to add that technologies are currently used for the process of retraining all ages of the population. Training of young people and retraining of the population is being steadily carried out, with special attention being paid to unemployed citizens of the country.

"Creating an innovation ecosystem" is the fifth direction and is aimed at further development of technological entrepreneurship with reliable and safe interaction between 3 key elements: business, science and the state. Closer to 2022, it is planned 
to create a large number of domestic technology companies that will have their success stories in this direction.

Digital Kazakhstan program is quite ambitious interms of results. In particular, by 2025 , the program should bring to the budget 1.7-2.2 trillion tenge, which is planned to be returned on the basis of added value. This amount is also 4.8-6.4 times higher than the invested investment funds. The main goal of work to maximize the introduction of digitalization in the country is that as a result of these processes, the entire country should be digitized and this will ensure a third of the GDP growth of the economy through these measures.

In 2022, performance growth in key sectors of the economy will increase from $20 \%$ to $50 \%$. This program will create 300 thousand new jobs (What is Industry 4.0? Figures and facts, 2016).

An international organization like the $\mathrm{UN}$ is developing a world-wide rating for ICT developmentthe ICT Development Index, which is calculated under the guidance of the UN. Since 2016, country has been ranked 52 .

In the UN ICT ranking, country's goal is to take the 30th place. The implementation of the program's directions should provide 1.6-2.2\% growth points closer to 2025. Another of the goals of the program is that in 2022, 5 cities of the country should appear among the smart cities.

It is also planned to change the provision of public services through online, so by $2022,80 \%$ of services will be provided in electronic form.

In order to fully implement the digitalization program, funds will be allocated annually from the budget, including 21.5 billion tenge in 2018, 33.1 billion tenge in 2019, 59.7 billion tenge in 2020, and 26.5 billion tenge in 2021 .

At present, in Kazakhstan, the cost structure for information and communication technologies is as follows:

- payment for services rendered from third-party organizations that work in the field of IT $-52 \%$;

- software support - 37\%,

- training workers to work with ICT-6\%,

- software development processes by organizations themselves $-5 \%$.

The structure of expenditures on ICT in pruning sectors of the economy looks like this:

$-31.1 \%$ in trade;

$-12.9 \%$ - in information and communication;

$-8.8 \%$ - in the manufacturing industry;

$-8.8 \%$ in the mining industry;

$-8.4 \%$ - in construction;

$-8 \%$ - in professional scientific and technical activities;
$-7.2 \%$ - in general government;

$-5.6 \%$ - in the field of transport and storage;

$-0.3 \%$ - in agriculture;

$-8.8 \%$ - in other industries (Most enterprises do not have access to "Industry 4.0", 2018).

The digital economy requires digital skills in the population to reap its benefits. However, currently the population's ability to use new computer technologies is $76.2 \%$. In this case, it is necessary to increase literacy in the near future.

Consider how the general situation and living conditions of the population have changed, taking into account the use of digital technologies in a pandemic.

For almost several months of forced quarantine, most of the population got used to the new rules of life. It turns out that many can work from home, cash is sometimes not needed at all, and purchases can be made online without even trying on. The question involuntarily comes to mind: Maybe after the pandemic a different world awaits us and how will life change after the quarantine ends?

1 st aspect in everyday life - will cash disappear and will cashless payments be used? Scientists believe that cash and plastic cards can keep the virus on themselves for up to several days. That is why many banks are developing recommendations on keeping banknotes up to 3-4 days before issuing them through an ATM, which ultimately guarantees the death of the virus (Without cash and offices, 2020).

It is believed that banknotes contribute to the spread of the virus. "In recent years, cash has been inexorably declining, and there are all the conditions for this: a good level of online banking, simple affordable transfers by phone number even between banks, high penetration of terminals with contactless payments. Moreover, bank cards are available to all categories of the population - from teenagers to pensioners".

However, contrary to the logic, the quarantine caused an increase in the turnover of cash. "In early spring of 2020, there was a new surge in the popularity of cash. It was caused by the regime of self-isolation and uncertainty in the economy. In April alone, the amount of cash withdrawn doubled. People were afraid that banks would be closed, that their savings would be worthless. In conditions of financial instability, it is quite understandable that people want to keep money at home, to feel that they are real. For the same instinctive reasons, people stocked up on food".

A complete rejection of cash after quarantine is not to be expected, that is, there is no certainty that the pandemic will cause a wave of technological 
breakthroughs in contactless payments, but it will certainly affect their popularity and contribute to the penetration of non-technology segments of the population. The development of payment by $\mathrm{QR}$ code will finally consolidate the success, which will be especially important for small and medium-sized businesses, a decrease in the commission for acquiring and the availability of services for self-employed, etc.

Aspect 2 - changing the format of employment, in other words, working from home, remotely. Since March 19 of 2020, when only enterprises providing livelihoods of the population have the right to keep work in offices, most organizations had to send workers on paid holidays or time off. But since the beginning of the epidemic, many companies have transferred employees to remote work.

Constant presence in the office is no longer a necessity. So, according to experts, at the time of the pandemic, employers, at least, had already thought and hypothesized which employees and business processes could switch to the format of remote work in the future so that the overall performance of the organization would not be affected?

Nevertheless, despite such work, there is a small number of information technology specialists in the domestic economy who have professional knowledge, skills and abilities.

The process of digitalization imposes higher requirements on the process of conducting work, including the process of functioning of entrepreneurs that existed in the modern market. The lack of communication and understanding between the employment sector and the workers ' sector can lead to retraining of personnel that the market does not need, and training of unnecessary workers. And this in turn can lead to imbalance between supply and demand, where the priority indicators are highquality training of specialists.

In connection with this situation, it is important to radically revise the education system in terms of training modern specialists with digital skills (Most enterprises do not have access to "Industry 4.0", 2018).

3 -aspect - changing the conditions for serving the population, in particular, the introduction of offline stores? Physical stores have long been under threat from the proliferation of online shopping. For example, in the first half of 2019, in a developed country like the United States, more than 7,000 traditionally operating offline points of sale have closed.

The situation with the pandemic only accelerated these processes: if before there were still fans of visiting shopping centers, touching everything with their hands and trying on, now there is simply no such opportunity. All purchases have to be done online. Online shopping is crowding out physical points of sale. The press service of the largest online store Wildberries confirmed that the demand for courier delivery has grown several times.

Since the beginning of the pandemic, we have noted a sharp - more than 3 times - growth in demand for the courier delivery service. The share of online purchases is growing due to an expanding audience and a more active transition to online. We note the growth of the 55+ audience in the online shopping segment: the older generation strives to minimize the number of social contacts. In addition, there is a significant increase in the number of online purchases among residents of small towns.

At the same time, the buyer can try on the goods at home and return them by calling a courier. In addition, the company is working on technological solutions: it launches 3D shoe fittings (selection of suitable shoe models, taking into account the characteristics of the buyer's foot), and plans its further development, for example, launching it in a mobile application. The work on the possibilities of virtual clothing fitting is also being updated. Another promising project is developing - these are automated points for issuing orders without employees - by analogy with stores without sellers. In the near future, the company expects the continued growth of online purchases (Without cash and offices, 2020).

It turns out that those technological trends that were only outlined in the past are progressing due to the pandemic. Probably, the processes that should have taken several years will take much less time.

Ensuring digital literacy of the population of any society is the key to its successful development, a priority task of the state. The implementation of a program for widespread development and provision of digital technologies in society is a guarantor and incentive to develop and increase the level and quality of life of citizens.

Using positive results of the digital economy is achieved only if all residents of the country have the skills to use digital technologies. In the current situation, the Ministry of education and science of the country is implementing new initiatives and proposals (Most enterprises do not have access to "Industry 4.0", 2018):

1) for the purpose to get acquainted with modern information technologies and training in information technologies, the subject "Information and communication technologies" was introduced for students of grades 3-4 who form general basic knowledge;

2) 372 circles on robotics are working, teaching General principles and basics of programming in the roar of robotics. 
In addition, it should be noted that the new requirements and regulations younger generation in accordance with the passage of time, it is planned to rework the content of secondary education by developing their creative thinking and technical skills.

By decision the Ministry of Education and Science of the Republic of Kazakhstan, the system of vocational, technical, higher and postgraduate education should be revised. (Report of the Minister of MID RK at the international forum "Digital Agenda in the Age of Globalization", 2018):

1 ) in order to form students' basic knowledge of ICT and their application in practice, the

subject "Information and Communication Technologies" was introduced on the basis of in excerpt three specialties;

2) new professional norms and standards are being created, which will become the main basis for educational programs of technical and professional, higher and postgraduate education.

With the active participation and support of the Samruk-Kazyna Fund in all regions of the republic, the State Program has been developed and is being implemented, which is aimed at developing the competitiveness of the country's economy, such as improving the level and quality of life of citizens of the Kazakh population. It is expected that the implementation of the Samruk- Kazyna Fund project can bring the state income, which, according to rough estimates, will amount to over two trillion tenge. Thus, digitalization should cover all areas of the life of Kazakhstan's society, business and the state.

The main and far from all advantages of this innovation process (digitalization) are, first of all, this will lead to the following positive changes from the project implementation: reducing costs, having reality in decision-making, stopping corruption, etc.

The main Central element of the Smart City project is the person and their needs. The efficiency of city and municipal services in the country is intended to be achieved through the introduction of digital technologies.

In the near future, the cities of Nur-Sultan and Almaty will become "smart cities" with the status of Smart City, and later the regional centers of Shymkent, Aktobe and Karaganda. The result of the development of "smart cities" is an increase in environmental friendliness, comfort of life, the efficiency of all services and the safety of life of city residents. (Report of the Minister of MID RK at the international forum "Digital Agenda in the Age of Globalization ", 2018).

The development of the Smart City concept is the result of the development of modern society and progressive world experience, which is based on the development model of European cities. The constituent components of this model are six subjects - "smart people", "smart economy", "smart life", "smart management", "smart environment" and "smart mobility". In the direction of the effective development of urban social and economic infrastructure, European experts have achieved a global breakthrough by developing such a model. The European experience was thoroughly studied in Kazakhstan, possibilities of using the Western model were developed, taking into account the possibility of adaptation to national conditions - social specifics and infrastructural features. The process of introducing and developing digitalization shows that Kazakhstan has received an effective tool to reduce the cost of utilities, save energy and financial resources, create a safe environment and other areas.

According to the experts of the Samruk-Kazyna Fund project, it is assumed that by 2022 most 5 cities of the country should appear among the smart cities.

As a result of the implementation of the national program "Digital Kazakhstan", where the defining direction is the construction of an innovative ecosystem, further development and support of startups in various sectors of the innovative economy will become. The main goal is to provide optimal conditions for increasing the capitalization and, consequently, the income of start-up projects. In the republic, by 2022 , it is planned to increase the volume of investments attracted to startups to 67 billion tenge (Industry 4.0, 2016).

Conclusion. Compared to the current period of economic development, digitalization in Kazakhstan will allow for significant outstripping growth. So, notes in the message of the President of the country to the citizens of Kazakhstan dated September 1,2020 , it was noted that: "Digitalization is not a fashion trend, but a key tool for achieving national competitiveness.

First of all, it is necessary to eliminate the digital divide, ensure maximum access to the Internet and high-quality communication for all citizens. Today, it is as basic a need as for drags and electricity. The development of the IT market, engineering and other high-tech services is not only the creation of added value and jobs within the country, more and more opportunities appear for the export of such services abroad. Interaction of the IT industry with the national business is seen as a promising direction" (Message from the President of RK Kassym-Jomart Tokayev to the people of Kazakhstan , 2020).

The development of the main branches of the digitalization economy, including processing 
production, transport and logistics related to transportation, agriculture, a new direction of trade-eCommerce, exchange of non-cash funds, application of new technologies in the financial sector. This is clearly evidenced by the world experience of industrially developed countries.

\section{References}

Chebotareva, E.E. (2017). Scientific research in the context of the digital economy // International Journal Of Open Information Technologies / Website: https: // cyberleninka. ru / journal / n / international-journal-of-open-information-technologies. - 3s. (Date of treatment 10.05.2020).

Chernykh, S.I. (2018). Digital economy and science // STAGE: economic theory, analysis, practice / Website: https: // cyberleninka. $\mathrm{Ru} /$ journal / $\mathrm{n} /$ etap-ekonomicheskaya-teoriya-analiz-praktika. - 5s. (Date of treatment 10.05.2020).

European Commission (2018). Shaping Europes digital future / https://ec.europa.eu/digital-single-market/en/news/digital-economy-and-society-index-2018-report. - 6p.

Flanders, J. (2017). Fruitful Conflict: Digital Research in the 21st Century // Digital Humanities: Reader / ed. M. Terrace, D. Nyhan, E. Vanhutta, I. Kizhner. - Per. from English - Krasnoyarsk: Sib. Feder. un-t. - 352 p.

Gribanov, Yu.I., Repin N.V. (2017). Review of the prospects for the application of new methods and management tools in the era of the digital economy. Management development for the transition to a digital economy // Materials of the X All-Russian (with international participation) scientific and practical conference. - P.33.

Industry 4.0 // NAG.ru [Site]. 02/12/2016. URL: http://nag.ru/articles / article / 28705 /industriya-4-0.html (accessed: 10.11.2016).

ISSEK HSE (2019). What is the digital economy? Trends, competencies, measurement of Ch-80 [Text]: reports. to XX Apr. int. scientific. conf. on the problems of economic and social development, Moscow, April 9-12. 2019 / G. I. Abdrakhmanova, K. O. Vishnevsky, L. M. Gokhberg and others; scientific. ed. L. M. Gokhberg; Nat. issled. University Higher School of Economics. - M .: Ed. house of the Higher School of Economics. - 82, [2] p. - 250.

Loshkarev, A.V., Tarasov V.V. (2018). Foreign experience as a means of improving legislation on the regulation of the digital economy. // Scientific and practical electronic journal “Alley of Science” № 9 (25). - M .. - S. 34-44.

Message from the Head of State Kassym-Jomart Tokayev to the people of Kazakhstan (2020). September 1, 2020. https: akorda. kz/ru/addresses/addresses_of_president.

Mukhtarova, K.S., Kozhakhmetova A.K (2017). High-tech projects of Kazakhstan: problems and prospects // Bulletin of KazNU. Economic series. - No. 1. - Almaty: Kazak University. - S.26-32.

Most enterprises do not have access to "Industry 4.0" (2018). / https://abctv.kz/ru/news/bolshinstvu-predpriyatij-nedostupna-industriya-4-0. (date of treatment 05/07/2020)

On the State Program "Informational Kazakhstan - 2020" (2018) / Decree of the President of the Republic of Kazakhstan dated January 8, 2013 No. 464. Abolished by the Decree of the President of the Republic of Kazakhstan dated May 5, 2018 No. 681.

Potluri Rajasekhara Mouly, Mukhtarova K.S., Tovma N.A., Dabyltayeva N.E., Chukubayev Y.S., Baikushikova G.S. (2020). Digitalization in the socio-economic sphere: content of development, foreign practices and results // INTERNATIONAL RELATIONS AND INTERNATIONAL LAW JOURNAL. - Almaty: al-Farabi Kzakh National University. - No. 2. - 0.88 p.1.

Report of the Minister of MID RK at the international forum "Digital Agenda in the Age of Globalization" (2018). / http:// miid.gov.kz/ru/pages/doklad-ministra-mir-rk-na-mezhdunarodnom-forume-cifrovaya-povestka-v-epohu-globalizacii (date of access 07/05/2020)

Semple M. (2017). Digital humanities do not so much create as share knowledge // Digital Humanities: a reader / ed. M. Terrace, D. Nyhan, E. Vanhutta, I. Kizhner. - Per. from English - Krasnoyarsk: Sib. Feder. un-t. - 352 p.

State program "Strategy" Kazakhstan-2050 “. - the official information resource of the Prime Minister of the Republic of Kazakhstan. - Nur-Sultan, (2020) .- 63p. https: // primeminister. kz / ru / documents / gosprograms / stratplan-2025.

The Economist (2014). Technology Isn't Working. / https:/www.economist.com/special-report/2014/10/02/technology-isntworking. -81 rubles.

Varavin E.V., Samusenko E.A. (2013). Analysis and forecasting of indicators of the effectiveness of the development of information and communication technologies in Kazakhstan // Digital Economy and Industry 4.0: state, problems, new challenges. - M. -40 p.

What is Industry 4.0? Figures and facts (2015). // Holz Expert [Site]. URL: http://holzex.ru/chtotakoe-industriya-4-0-tsifryi-ifaktyi/ (date of access: 27.11.2016)

Website of the Global Center for Digital Business transformation (2018). URL: https: // www. imd.org / dbt / digitalbusinesstransformation (date accessed: 06.12.2018).

Without cash and offices: what will our life be like after the pandemic? (2020). // https://hi-tech.mail.ru/review/world_after_corona. (date of treatment 05/07/2020)

World Bank (2016). Digital Dividends / World Development Report. - 58 p. / https: // openknowledge. worldbank.org/bitstream/ handle/10986/23347/210671RuSum.pdf? sequence $=16$.

Ziyadin, S., Koryagina, E., Grigoryan, T., Tovma, N., Ismail, G.Z. (2019). Specificity of using information technologies in the digital transformation of event tourism. International Journal of Civil Engineering and Technology Volume 10, Issue 1, January. - Pages 998-1010. 